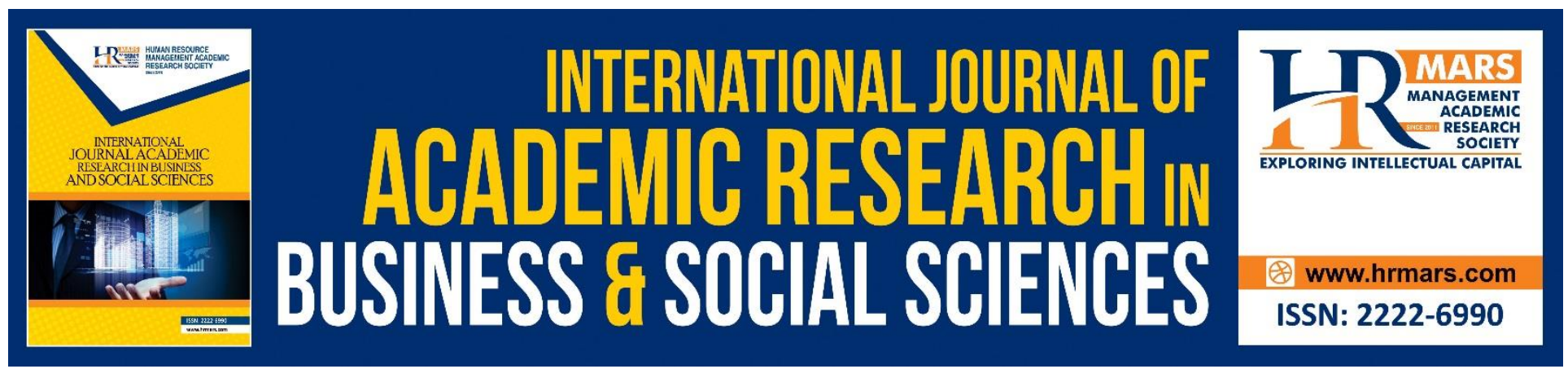

\title{
Does Zakat Significantly Impact on Economic Growth in Selangor, Malaysia?
}

Ahmad Syubaili Bin Mohamed, Amir Aiman Bin Ibrahim, Nurul Syuhada Binti Zaidi, Mohd Naim Bin Kamaruzaman

To Link this Article: http://dx.doi.org/10.6007/IJARBSS/v9-i6/6033

DOI: 10.6007/IJARBSS/v9-i6/6033

Received: 14 April 2019, Revised: 12 May 2019, Accepted: 12 June 2019

Published Online: 27 June 2019

In-Text Citation: (Mohamed, Ibrahim, Zaidi, \& Kamaruzaman, 2019)

To Cite this Article: Mohamed, A. S. Bin, Ibrahim, A. A. Bin, Zaidi, N. S. B., \& Kamaruzaman, M. N. Bin. (2019). Does Zakat Significantly Impact on Economic Growth in Selangor, Malaysia? International Journal of Academic Research in Business and Social Sciences, 9(6), 786-807.

Copyright: (C) 2019 The Author(s)

Published by Human Resource Management Academic Research Society (www.hrmars.com)

This article is published under the Creative Commons Attribution (CC BY 4.0) license. Anyone may reproduce, distribute, translate and create derivative works of this article (for both commercial and non-commercial purposes), subject to full attribution to the original publication and authors. The full terms of this license may be seen

at: http://creativecommons.org/licences/by/4.0/legalcode

Vol. 9, No. 6, 2019, Pg. $786-807$

http://hrmars.com/index.php/pages/detail/IJARBSS

JOURNAL HOMEPAGE

Full Terms \& Conditions of access and use can be found at http://hrmars.com/index.php/pages/detail/publication-ethics 


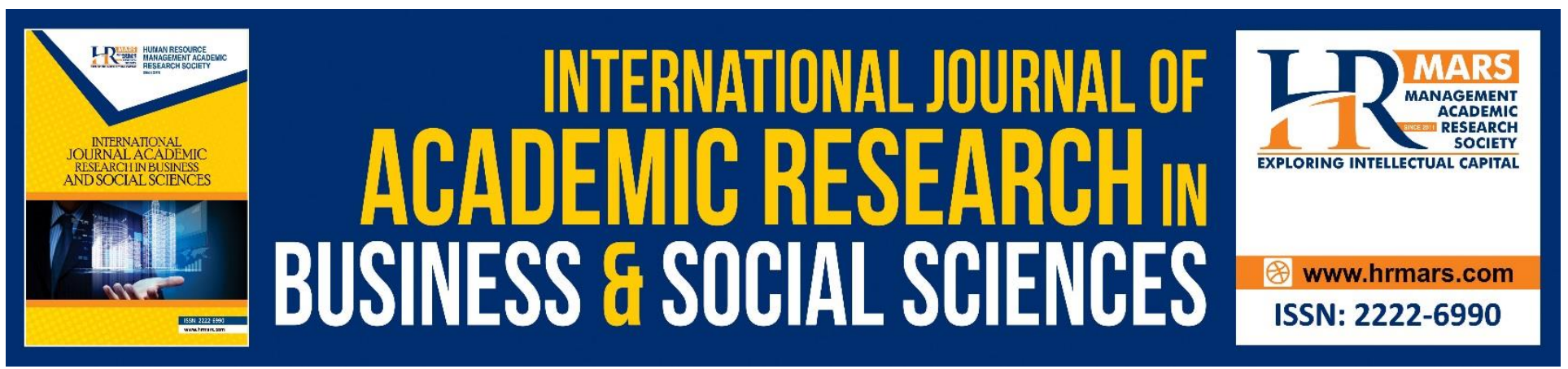

\title{
Does Zakat Significantly Impact on Economic Growth in Selangor, Malaysia?
}

\author{
Ahmad Syubaili Bin Mohamed ${ }^{1}$, Amir Aiman Bin Ibrahim², Nurul \\ Syuhada Binti Zaidi ${ }^{3}$, Mohd Naim Bin Kamaruzaman ${ }^{4}$ \\ 1,2,3,4 Faculty Economics and Business, University Malaysia Sarawak (UNIMAS),

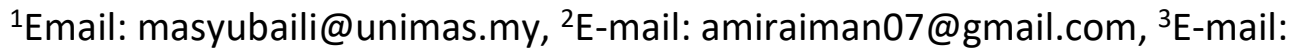 \\ znsyuhada@unimas.my, ㅌ-mail:kmnaim@unimas.my
}

\begin{abstract}
Zakat is an instrumented fund that is so dynamic that it is recognized as an economic instrument that can reduce the incidence of poverty is also the heart of the Islamic economy. The main objective of this research is to comparative relationship contribution of the collection of zakat and gross domestic product to the unemployment rate and poverty in Selangor. To conduct the research, the data from the year 2012 to 2016 were collected, consisting of 2 dependents variable which is poverty and unemployment rate and 2 independents variable is a collection of zakat and gross domestic product. Based on the results, there are significant relations between zakat, gross domestic product to poverty in Selangor which is measured using ordinary least square. While the decision is otherwise for the unemployment rate there is a negative significant relationship to the collection of zakat and gross domestic product. Meanwhile, the correlation analysis is a statistically significant relationship between gross domestic product and zakat perfect negative relationship exists. This indicates that a higher collection of zakat and gross domestic product induces alleviating poverty. In the meantime, the correlation analysis is not a statistically significant relationship between gross domestic product and zakat to the unemployment rate and perfect positive relationship exists. This shown dependent variable does not give effect to decrease the unemployment rate in Selangor. Furthermore, this study is achieving the objectives are given and it can implement along with other research and policymakers.
\end{abstract}

Keywords: Zakat, Poverty, Gross Domestic Product, Unemployment Rate, Head Count Index, Economic Growth

\section{Introduction}

Zakat is the amount which is imposed on the Muslims that which is the third pillar of Islam. The main reason is to help our brothers and sisters in need. Engaged in Selangor, recognized as The Lembaga Zakat Selangor (LZS) is a trust-based organization ensure that implemented to distribution and collection be able to follow with legislation requirement. Asnaf Fakir is a Muslim with no properties, 
incomes, and earnings but not $50 \%$ of his self-esteem and reliance boundaries. Various types of help have been given to those in need in particular to the needy and poor. LZS is responsible for managing all of the resources of this charity. Collection and distribution were made to meet the demands of religion for the welfare of his people. History proves that management with efficient service, charity as a natural instrument capable of eradicating poverty (Kadri, Ahmad, \& Mohd Noor, 2012) as well as ensuring social balance within the Muslim community. Furthermore, claimed by LZS zakat in Selangor also reducing unemployment by creating job opportunities and also creating business opportunities with help is given in the form of capital, improving entrepreneurial knowledge, financial management, marketing, product high-quality and brand, continuous guidance and monitoring. To date, a whole of 1,300 people has become entrepreneurs.

The economy of Selangor is a highly developed and successful free market economy. Per capita gross domestic product (GDP) per capita is among the highest in Malaysia after Kuala Lumpur, which is about 37,851 Malaysian Ringgit in 2016. Export, industrial, agricultural and service sectors are the most important aspects of the Selangor economy. The indexing sector is a major contributor to the state's economic turbulence, accounting for over $58 \%$ of GDP in 2008, but it is the national economic pulse. Apart from the industrial and ports, the agriculture sector is also growing despite contributing only $3.1 \%$ to the state GDP. The contribution of more than 20 per cent Selangor to Malaysia's GDP proves stable finance through the strengthening of effective governance and policy aspects. According to a report by the Department of Statistics, from 2012 to 2015, Selangor has recorded GDP growth over the Federal Government for four consecutive years. Selangor not only recorded a robust growth of GDP but managed to overcome growth at the Federal level for six consecutive years, from 2012 to 2017.

In Selangor Malaysia, which is one of the fastest developing states in the country provides various economic and employment opportunities to its residents. That is proud of the country is not only prosperous with 5.8 million people but 52.5 per cent of them are Muslims. However, awareness of the importance of fulfilling the obligation to pay zakat among Muslims in Selangor is still not satisfactory even though the amount of zakat collection increases every year. In 2015, the total amount of the collection was RM627.2 million, but from the three million Muslims of Selangor, only 256,001 people were zakat producers whereas the total number of asnaf needs in Selangor is now at RM1 billion. The LZS is responsible for that proposes to solve state poverty and provide financial support to eligible people but have not positioned LZS on various factors.

In terms of poverty economic analysts argue that the current poverty index is no longer relevant and should be thoroughly assessed. Based on Abdul Latif (1998) stated the poverty line cannot be determined based on physical factors, for example, household income only as it is currently applied. It needs to be expanded, especially the social aspect by re-evaluating the cost of expenditure as well as locations affecting the cost of living. There are two poverty criteria, which can be evaluated based on household income and another factor such as a burden that cannot be evaluated according to household income.

Selangor became the stated largest contributor to the GDP. However, GDP in Selangor, not the main cause the problem faced is also due to the unemployment rate and include poverty. There is related between this gross domestic product and unemployment rate and poverty. GDP measures the total value of goods and services released in the economy it means needing a job to produce a 
INTERNATIONAL JOURNAL OF ACADEMIC RESEARCH IN BUSINESS AND SOCIAL SCIENCES

Vol. 9, No. 6, June, 2019, E-ISSN: 2222-6990 @ 2019 HRMARS

product. If no job unemployment rate will be increasing including poverty. The solution is that the state aid centre plays an important role in addressing this problem.

\section{Research Objective}

The main objective of this research is to comparative relationship contribution of the collection of zakat and gross domestic product to the unemployment rate and poverty in Selangor. This study specifically addresses the following objectives:

i. To investigate the relationship between zakat and gross domestic product to the unemployment rate and poverty.

ii. To examine the impacts between collection zakat to poverty and unemployment rate.

iii. To investigate the impacts between of gross domestic product to poverty and unemployment rate.

\section{Literature Review}

Many studies have seen zakat systems from various perspectives and mostly centred on zakat accumulation and distribution and strategies to improve the effectiveness of zakat collection and distribution. According to Amir Osman (2007), among the studies that have been carried out include the study on the potential payment and collection of zakat in Malaysia and a study on the acceptance and ownership of the community on the permissible zakat resources (Ahmad \& Wahid, 2005), the distribution of zakat to eight asnaf (Wahid \& Ahmad, 2009), amil perception and zakat recipients on the proposal to localize the distribution of zakat (Wahid, 2011; Wahid \& Abdul Kader, 2011), the stabilization of the zakat and tax system towards the economic progress of the ummah (Abdul Majid, 2003) and the role of zakat distribution in raising the economic level of the ummah (Ibrahim, 2007) . This study aims to raise the public's awareness of the obligation to pay zakat collection so that the amount of zakat can be increased, thus enhancing the quality of life of zakat, especially the poor and the poor by increasing the distribution of zakat and providing various assistance to them. The past studies from Ibrahim (2006) find out about the purpose of zakat in Selangor get hold of efficaciously reduced the incidence of poverty in that state. Furthermore, according to Ibrahim (2007) through observation carried out on the 2001-2002 data for the result of poverty distribution on the poverty recipients of zakat in Selangor that indicate his figured out the distribution of zakat can bring down poverty rate from $62 \%$ to $51 \%$ while poverty gap be brought down from RM315 to RM281.

Much of the current literature on zakat pays particular attention to the study on how Islamic way to disposing of impoverishment in Nintavur Sri Lanka by evaluating the role of zakat through qualitative and quantitative whereby between 2010 until 2014 that data have been gathered (Suheera, Nashri \& Jamaldeen, 2015). What we know descriptive analysis is based on a method by utilizing information both primary and secondary sources. They found that the accumulation of zakat will conscious about how important it of zakat in order is to lighten destitution, the execution of aggregate zakat, the significance of preparing and ability advancement to enhance the gathering zakat for making powerful in mitigating the idea of poverty. Based on the study conducted by Jaelani (2015) discovered that zakat collection had been a problem-solving approach to eradicate poverty in Indonesia. By using data from the descriptive method which is secondary data records had been utilized for this study can be implemented and with collaboration the effort stakeholders and 
government regulation of Indonesia. In addition, the previous study was supported by (Kabir Hassan \& Masrur Khan, 2007) stated that on the off chance that zakat fund appropriately well managed this will cause decrease the foreign useful resource and essentially include debt burden be reduced.

As Rosly (2008) points out, zakat is an essential element of the Open Fund in Islam and takes on an important role in the destitution annihilation and re-distribution of Muslim people. Overall, zakat organization manages the collection of zakat from zakat payers and the transfer of zakat to the 8 beneficiaries (Asnafs). He explained for instance, that the increasing number of shares held by Muslims in companies like organizations which use the Islamic name has provided a strong basis for an intentional and successful zakat collecting and dissemination arrangements. Traditionally, it has been argued that (Johari, 2004; Ibrahim, 2006; Ramli \& Ibrahim, 2010; Ali \& Fahme, 2011; Fahme et al., 2013) have pointed out from their research that zakat possesses extensive impact in lead the direction of improving the income distribution of the poverty. Because of that, this studies to figure out how the effectiveness of zakat intelligibly can lower level of poverty occurrence in complimenting and improve the past research and literature in Kelantan, Malaysia.

According to Hassan \& Khan (2007) gauge the result on of zakat collection on the annual advancement way of Bangladesh. The zakat collection can augment the taxation capability of the government into and out of the enhancement of productivity, employment and output. Hence this will affect the unemployment rate. Additionally, the implementation of zakat in Bangladesh has quite a few achievable brings about on government budgets such as relieving allocate classification pick out for poverty alleviation for supplementary budgetary need, multiply the achievable of taxation along with the enhancement of productivity, employment and output. Additionally, the zakat funds can be used on the government as a beneficial economic plan implement for country's development. According to Fazeela (2014) have clarified search about zakat it can reduce poverty by $10 \%$ and influenced to raise the income of $35 \%$ of people likewise as many as $31 \%$ of the people will obtain an occupation.

The relationship between the unemployment rate and economic growth also carried out by (Onwachukwu 2015) in Nigeria. In the study, two variables are estimated which include unemployment and inflation. He investigates the impact of unemployment and inflation on the economic growth in Nigeria from 1985 to 2010. The study had shown that unemployment does not have a large impact on the economic growth in Nigeria. However, in Nigeria, inflation had a significant impact on economic growth. In the study also recommend the government to establish more organizations and forced the workers that reached retirement age to leave the organization. This action is to give the working opportunity to unemployed youths. Meanwhile, GDP proofed will improve economic growth especially lowering the unemployment rate. This is proofed by Khan, Khattak, \& Hussain (2008) that have a study conducted in the year 1960 until 2005 from time series data about the inter-relationship of GDP growth and unemployment in Pakistan. In the early stage, test proceeds with Augmented Dickey-Fuller (ADF) and at the point they utilized the Johansen Coincorporation that for the first outcome had been variance. From that test, shows bring down unemployment by $0.63 \%$ when $1 \%$ increases in GDP, another viewpoint when GDP multiplied by $7.25 \%$ and $1 \%$ from unemployment decrease again. Their outcomes additionally demonstrated that GDP over the long run had a terrible relationship with joblessness. 
Jaradat (2013) studied the effect on the unemployment rate and inflation in Jordan. The research was conducted from 2000 until 2010 on the effect on unemployment and inflation on Jordanian GDP. That research indicates that negative significant relationship between gross domestic product and unemployment when outcomes showed that bring down in the unemployment percentage compared to a gross domestic product by $0.697 \%$ and $1 \%$. Besides that, inflation and gross domestic product both showed increased when inflation increase and this means unemployment and inflation give impact to a gross domestic product in Jordanian. Based on (Hadroj, n.d.) ensure that gross domestic product falling and will cause unemployment rising because of these two main characteristics of an economic recession. Besides that, a study by Hussain (2010) shows the same result with Jaradat past studies which proves standard outcome confirmed that gross domestic product growth rate and unemployment will have a negative relationship which was held in 1972 to 2006 between economic growth and unemployment in Pakistan. They are using Augmented DickeyFuller test and get the difference for at initially when for unit root and all variables were stationary. Therefore, they proceed with Johansen Co-integration to take a look at for a long-run relationship between the variables. Based on Adam Smith is a classical economist explained that poverty something deficiency to the individual what basic necessity to live a decent life.

Kwasi (2017) studies in 1981 until 1995 and 1996-2005 shows that have regional progression in GDP and poverty reduction. Due to the fact choose on those two-time periods that a clear shift in the mid-1990s because at the time economic growth in development in creating countries took off. That makes Kwasi looked to investigate was the manner by which that expanding development at the dimension of whole nations has happened as far as income growth and poverty decrease. His findings exhibit that GDP increase has led on average, to income growth in many parts of the world. That is been an essential driving force at the back of poverty reduction. His findings exhibit that GDP development has led, on average, to income growth in many parts of the world. That is been an essential driving force at the back of poverty reduction. Meanwhile, Ravallion (2011.) shows the poor for the most part do share in the advantages of rising prosperity, and they commonly do go through from the economic slump. However, there is a substantial discrepancy all on sides the ordinary results for the poor. One source of discrepancy is that the economic growth rate calculated does no longer every time consider the regular living standards.

\section{Research Methodology}

The research as stated two independent variables which is zakat and gross domestic product that could have an impact on dependent variables either increasing or decreasing to the unemployment rate and poverty in Selangor Malaysia. This research conducted on Selangor, Malaysia is used of 5 years annual data which is retrieved from World Bank Database and Pusat Pungutan Zakat (PPZ). This data collection for research is used 5 years from 2012 to 2016 that manage to study about the effect of the relationship between zakat, a gross domestic product intended for the independent variable in Selangor and unemployment rate, poverty which is the dependent variable. All data is retrieved from the World Bank Database, Website Zakat Malaysia and Data Stream. According to the data have been collected will be imported and explore through Microsoft Excel by using E-views 10 . The empirical model to be examined in this study is expressed as follow: 
Model 1: $\mathrm{HCl}=f($ Zakat $)$

Model 2: $\mathrm{HCl}=f(G D P)$

Model 3: UR $=f$ (Zakat)

Model 4: UR $=f(G D P)$

While the conceptual framework used in this study is specified as below.

$$
\begin{aligned}
\text { Model 1: HCl } & =\beta_{0}+\beta_{1} \text { ZKT }+\varepsilon_{t} \\
\text { Model 2: } \mathrm{HCl} & =\beta_{0}+\beta_{1} \mathrm{GDP}+\varepsilon_{\mathrm{t}} \\
\text { Model 3: UR } & =\beta_{0}+\beta_{1} \text { ZKT }+\varepsilon_{\mathrm{t}} \\
\text { Model 4: UR } & =\beta_{0}+\beta_{1} \mathrm{GDP}+\varepsilon_{\mathrm{t}}
\end{aligned}
$$

Whereby, $\beta$ represents as reaction of coefficient measure in the model while $\beta_{0}$ acts constant coefficient. This model includes:

$$
\begin{aligned}
& \text { UR = Unemployment Rate } \\
& \mathrm{HCl}=\text { Headcount Index (status poverty measurement) } \\
& \text { ZKT = Zakat } \\
& \text { GDP = Gross Domestic Product }
\end{aligned}
$$

Therefore, the model expressed above is used to study and analyze the relationships which exist between the explanatory variable and explained variable in Selangor using simple methods. In data analysis, software E-views 10 will run the time series data selected to obtain precise and appropriate results of this study. The significant test which is about to be conducted is Ordinary Least Squares (OLS), Normality test (JB), Heteroskedasticity test (BP), Serial Correlation (BG), GrangerCausality, Hodrick-Prescott (HP) test. Accordance with the objectives of this research, the hypothesis used to be formed:

$H_{1}$ : There is a significant relationship between $\mathrm{HCl}$ with ZKT

$\mathrm{H}_{2}$ : There is a significant relationship between $\mathrm{HCl}$ with GDP

$\mathrm{H}_{3}$ : There is a significant relationship between UR with ZKT

$\mathrm{H}_{4}$ : There is a significant relationship between UR with GDP

\section{Findings and Discussions}

\section{Model 1}

Table 1: OLS Model 1 result for $\left(\mathrm{HCl}=B_{0}+L Z K T\right)$

\begin{tabular}{|l|l|l|l|l|}
\hline Variable & Coefficient & Standard Error & T-Statistic & Probability \\
\hline C & 20.02700 & 1.719096 & 11.64973 & 0.0014 \\
\hline LKZT & -0.983881 & 0.085305 & -11.53368 & 0.0014 \\
\hline R-squared & 0.977945 & Adjusted R-squared & 0.970594 \\
\hline F-statistic & 133.0257 & Prob (F-Statistic) & 0.001399 \\
\hline
\end{tabular}

Note: Significant level: $5 \%$

Table 1 above presents the ordinary least square method model for $\mathrm{HCl}=$ LZKT for the sample of 5 years' time series data observation in Selangor Malaysia. In this result, the equation formed as:

$$
\mathrm{HCl}=20.0270-0.983881 \mathrm{LZKT}+\varepsilon
$$


Whereby, $\mathrm{HCl}$ is represented by poverty and LZKT for zakat and $\varepsilon$ represents the error term. $\mathrm{HCl}$ and LZKT have a positive relationship. If LZKT increase by $1 \% \mathrm{HCl}$ will be decreased by 0.983881 units. The Head Count Index $(\mathrm{HCl})$ and Zakat's collection in the country of Malaysia, therefore, have inverse relations. It means that poverty can be reduced if zakat collection is significantly increased. It is a significant relationship because the probability value is lower than 5 per cent. For this test, the hypothesis is rejected as the $\mathrm{p}$-value is less than the value of 5 per cent. In this estimated model, the value of R2 is 0.9779 (98.0 \%) which means that the good fitness of the predicted regression line is $98.0 \%$. It is thus understood that model 1 estimated regression line is nicely fitted.

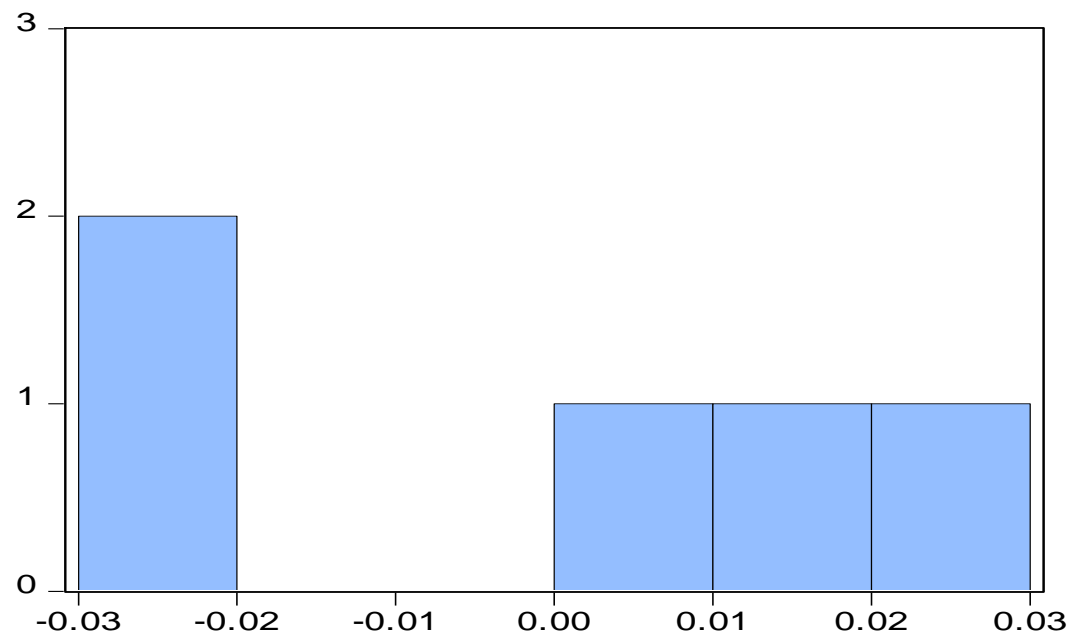

\begin{tabular}{|lr|}
\hline \multicolumn{2}{|l|}{ Series: Residuals } \\
Sample 2012 2016 \\
Observations & 5 \\
Mean & $1.42 e-15$ \\
Median & 0.003279 \\
Maximum & 0.029861 \\
Minimum & -0.026334 \\
Std. Dev. & 0.023481 \\
Skewness & 0.050403 \\
Kurtosis & 1.530676 \\
& \\
Jarque-Bera & 0.451891 \\
Probability & 0.797762 \\
\hline
\end{tabular}

Diagram 1: Normality test for Model 1

The normality test for model 1 is presented in Diagram 1 . The residual should normally be distributed based on a good model. The "residual is normally distributed" is null hypothesis is accepted as the corresponding Jarqure-Bera probability value is more than $5 \%(79.8 \%)$ also this is the equivalent value. This is means do not reject the null hypothesis. Therefore, "The residual is not normally distributed" is rejected in the alternative hypothesis. It shows the model 1 is a good model.

Table 2: Heteroskedasticity Test for Model 1

\begin{tabular}{|l|l|l|l|}
\hline Heteroskedasticity Test: Breusch-Pagan-Godfrey \\
\hline F-statistic & 0.093251 & Prob. F(1,3) & 0.7800 \\
\hline Obs*R-squared & 0.150733 & Prob.Chi-Square (1) & 0.6978 \\
\hline Scaled explained SS & 0.014398 & Prob. Chi-Square(1) & 0.9045 \\
\hline
\end{tabular}

The results above of model heteroskedasticity tests are explained in Table 2. No heteroskedasticity in the residual, therefore null hypothesis not rejected because the probability value of the R-square is more than 5 per cent (probability more than 0.05 significant level observed). This means that the probability value is $69.78 \%$ which is a significant level is higher than $5 \%$. Based on this result it is not heteroscedastic, but homoscedastic in terms of residues of model 1.

Table 3: Serial Correlation Test for Model 1 
INTERNATIONAL JOURNAL OF ACADEMIC RESEARCH IN BUSINESS AND SOCIAL SCIENCES

Vol. 9, No. 6, June, 2019, E-ISSN: 2222-6990 @ 2019 HRMARS

\begin{tabular}{|l|l|l|l|}
\hline Breusch-Godfrey Serial Correlation LM Test \\
\hline F-statistic & 0.017396 & Prob. $F(1,2)$ & 0.9071 \\
\hline Obs*R-squared & 0.043116 & Prob. Chi-Square(1) & 0.8355 \\
\hline
\end{tabular}

Whether its serial correlation that is autocorrelation or serial correlation in the residual should not be both of it. Table 3 shows that the R-squared observed is more than 5 per cent ( 83.55 per cent) of the corresponding probability. Hence it is impossible to reject the null hypothesis and it there is no serial correlation in the residual, rather it is accepted. Consequently, in model 1 there is no autocorrelation or serial correlation.

\section{Model 2}

Table 4: OLS Model 2 result for $\left(\mathrm{HCl}=\mathrm{B}_{0}+\mathrm{LGDPT}\right)$

\begin{tabular}{|l|l|l|l|l|}
\hline Variable & Coefficient & Standard Error & T-Statistic & Probability \\
\hline C & 21.71739 & 0.671824 & 32.32601 & 0.0001 \\
\hline LGPDT & -1.745554 & 0.054499 & -32.02900 & 0.0001 \\
\hline R-squared & 0.997084 & Adjusted R-squared & \\
& & & 0.996112 \\
\hline F-statistic & 1025.857 & Prob (F-Statistic) & 0.000067 \\
\hline
\end{tabular}

Note: Significant level: $5 \%$

Table 4 above presents the ordinary least square method model for $\mathrm{HCl}=$ LGPDT for the sample of 5 years' time series data observation in Selangor Malaysia. In this result, the equation formed as:

$$
\mathrm{HCl}=21.71739-1.745554+\varepsilon
$$

Whereby, $\mathrm{HCl}$ is represented by poverty and LGPDT for gross domestic product and $\varepsilon$ represents the error term. $\mathrm{HCl}$ and LGPDT have a positive relationship. If LGPDT increase by $1 \% \mathrm{HCl}$ will be decreased by 1.745554 units. The Head Count Index $(\mathrm{HCl})$ and Gross Domestic Product collection in the country of Malaysia, therefore, have inverse relations. It means that poverty can be reduced if gross domestic product collection is significantly increased. It is a significant relationship because the probability value is lower than 5 per cent. For this test, the hypothesis is rejected as the p-value is less than the value of 5 per cent. In this estimated model, the value of R2 is 0.9970 (99.0 $\%)$ which means that the good fitness of the predicted regression line is $99.0 \%$. It is thus understood that the model 2 estimated regression line is nicely fitted. 


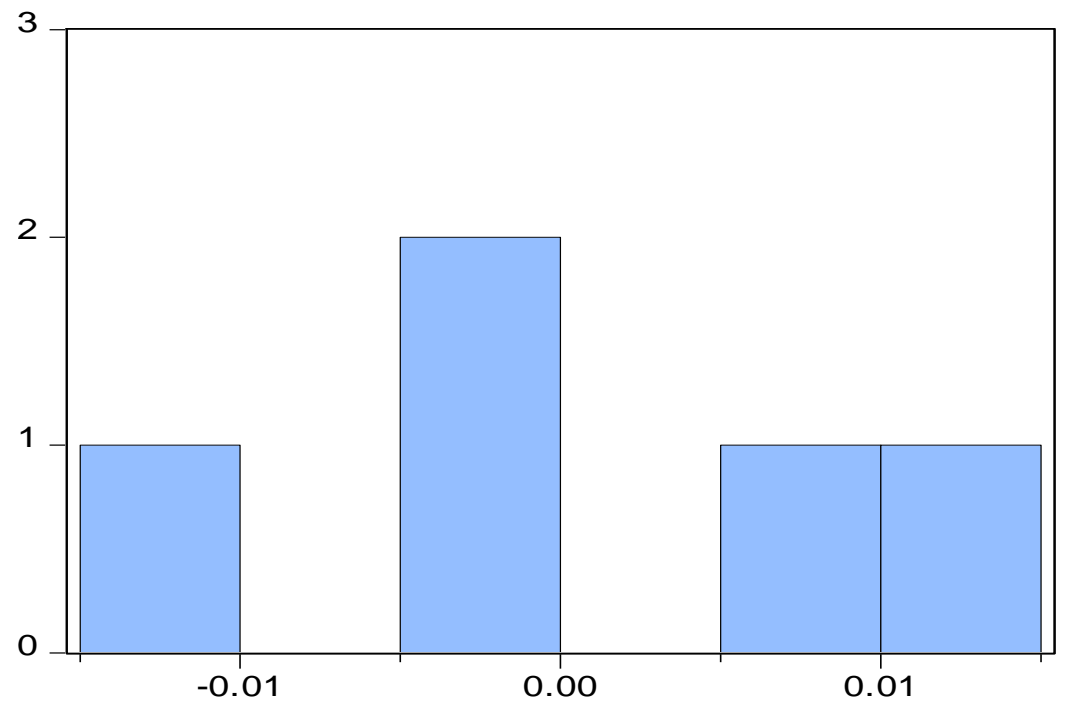

$\begin{array}{lr}\text { Series: Residuals } \\ \text { Sample 2012 } 2016 \\ \text { Observations } \\ \text { Mean } \\ \text { Median } & 0.000000 \\ \text { Maximum } & -0.003148 \\ \text { Minimum } & 0.010007 \\ \text { Std. Dev. } & -0.010399 \\ \text { Skewness } & 0.008538 \\ \text { Kurtosis } & 1.496005 \\ & \\ \text { Jarque-Bera } & 0.482002 \\ \text { Probability } & 0.785841\end{array}$

Diagram 2: Normality test for Model 2

The normality test for model 2 is presented in Diagram 2. The residual should normally be distributed based on a good model. The "residual is normally distributed" is null hypothesis is accepted as the corresponding Jarqure-Bera probability value is more than $5 \%(78.6 \%)$ also this is the equivalent value. This is means do not reject the null hypothesis. Therefore, "The residual is not normally distributed" is rejected in the alternative hypothesis. It shows the model 2 is a good model.

Table 5: Heteroskedasticity Test for Model 2

\begin{tabular}{|l|l|l|l|}
\hline Heteroskedasticity Test: Breusch-Pagan-Godfrey \\
\hline F-statistic & 6.666317 & Prob. F(1,3) & 0.0816 \\
\hline Obs*R-squared & 3.448220 & Prob.Chi-Square (1) & 0.0633 \\
\hline Scaled explained SS & 0.304824 & Prob. Chi-Square(1) & 0.5809 \\
\hline
\end{tabular}

The results above of model heteroskedasticity tests are explained in Table 5. No heteroskedasticity in the residual, therefore null hypothesis not rejected because the probability value of the R-square is more than 5 per cent (probability more than 0.05 significant level observed). This means that the probability value is $6.33 \%$ which is a significant level is higher than $5 \%$. Based on this result it is not heteroscedastic, but homoscedastic in terms of residues of model 2.

Table 6: Serial Correlation Test for Model 2

\begin{tabular}{|l|l|l|l|}
\hline \multicolumn{4}{|l|}{ Breusch-Godfrey Serial Correlation LM Test } \\
\hline F-statistic & 0.079983 & Prob. $F(1,2)$ & 0.8039 \\
\hline Obs*R-squared & 0.192269 & Prob. Chi-Square(1) & 0.6610 \\
\hline
\end{tabular}

Whether its serial correlation that is autocorrelation or serial correlation in the residual should not be both of it. Table 6 shows that the R-squared observed is more than 5 per cent ( 66.10 per cent) of the corresponding probability. Hence it is impossible to reject the null hypothesis and it there is no serial correlation in the residual, rather it is accepted. Consequently, in model 2 there is no autocorrelation or serial correlation. 
INTERNATIONAL JOURNAL OF ACADEMIC RESEARCH IN BUSINESS AND SOCIAL SCIENCES

Vol. 9, No. 6, June, 2019, E-ISSN: 2222-6990 @ 2019 HRMARS

\section{Model 3}

Table 7: OLS Model 3 result for (LURT $\left.=B_{0}+L Z K T\right)$

\begin{tabular}{|l|l|l|l|l|}
\hline Variable & Coefficient & Standard Error & T-Statistic & Probability \\
\hline C & -6.892744 & 11.36940 & -0.606254 & 0.5871 \\
\hline LZKT & 0.899728 & 0.564173 & 1.594774 & 0.2090 \\
\hline R-squared & 0.458807 & Adjusted R-squared & \\
& & & 0.278409 \\
\hline F-statistic & 2.543305 & Prob (F-Statistic) & 0.209027 \\
\hline
\end{tabular}

Note: Significant level: $5 \%$

Table 7 above presents the ordinary least square method model for LURT = LZKT for the sample of 5 years' time series data observation in Selangor Malaysia. In this result, the equation formed as:

$$
\mathrm{HCl}=-6.892733+0.899728+\varepsilon
$$

Whereby, LURT is represented unemployment rate and LZKT for zakat and $\varepsilon$ represents the error term. LURT and LZKT have a negative relationship. If LZKT increase by $1 \%$ LURT will be decreased by 0.899728 units. The unemployment rate (LURT) and zakat collection in the country of Malaysia, therefore, it not inverse relations. It means that the unemployment rate not changed if zakat collection is significant whether it increase or decrease. It is not a significant relationship because the probability value is higher than 5 per cent. This test does not reject the null hypothesis as the $p$-value is higher than the value of 5 per cent. In this estimated model, the value of R2 is 0.4588 (46.0\%) which means that the good fitness of the predicted regression line is $46.0 \%$. It is thus understood that model 3 estimated regression line is nicely fitted.

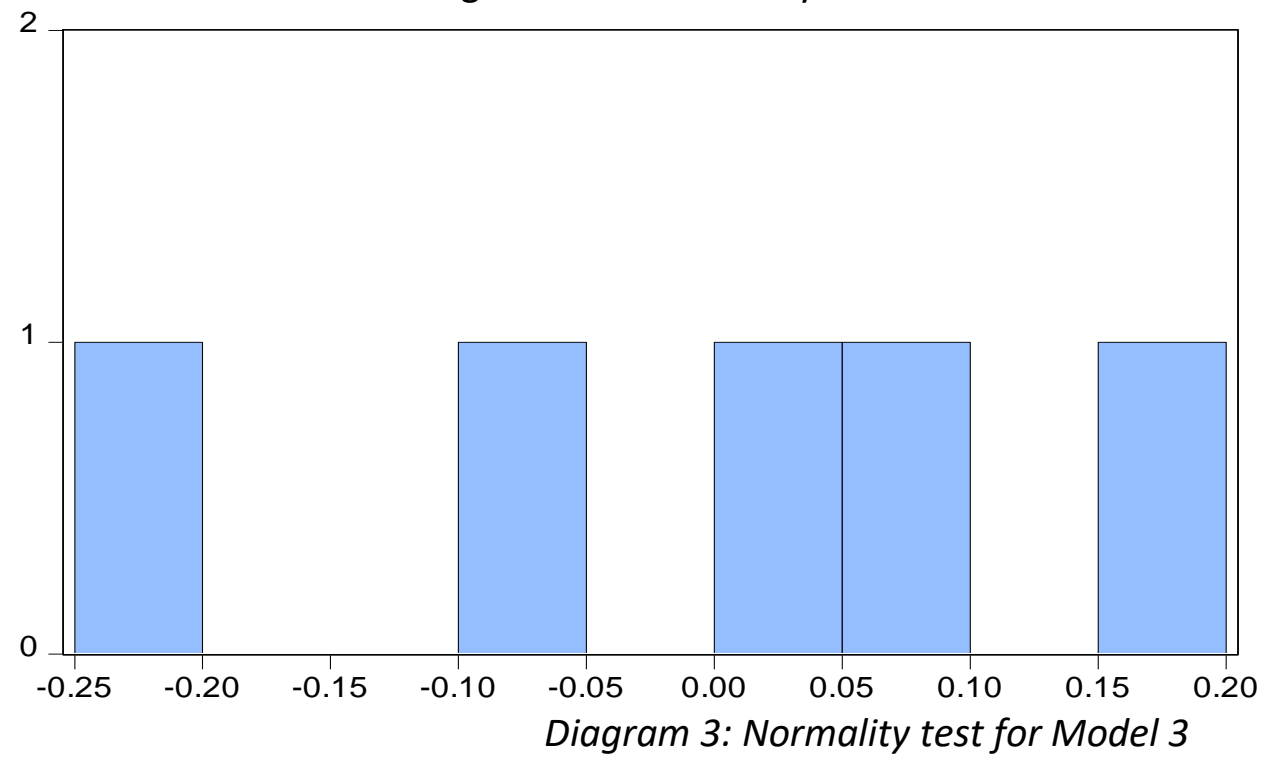

Series: Residuals

Sample 20122016

Observations 5

Mean

0.000000

Median

0.037320

Maximum

0.187079

Minimum

$-0.224411$

Std. Dev.

0.155295

Skewness

$-0.350898$

Kurtosis

2.047221

Jarque-Bera $\quad 0.291730$

Probability

0.864274

The normality test for model 3 is presented in Diagram 3 . The residual should normally be distributed based on a good model. The "residual is normally distributed" is null hypothesis is accepted as the corresponding Jarqure-Bera probability value is more than $5 \%(86.4 \%)$ also this is the equivalent value. This is means do not reject the null hypothesis. Therefore, "The residual is not normally distributed" is rejected in the alternative hypothesis. It shows the model 3 is a good model. 
INTERNATIONAL JOURNAL OF ACADEMIC RESEARCH IN BUSINESS AND SOCIAL SCIENCES

Vol. 9, No. 6, June, 2019, E-ISSN: 2222-6990 @ 2019 HRMARS

Table 8: Heteroskedasticity Test for Model 3

\begin{tabular}{|l|l|l|l|}
\hline Heteroskedasticity Test: Breusch-Pagan-Godfrey \\
\hline F-statistic & 0.995745 & Prob. F(1,3) & 0.3919 \\
\hline Obs*R-squared & 1.246007 & Prob.Chi-Square (1) & 0.2643 \\
\hline Scaled explained SS & 0.234872 & Prob. Chi-Square(1) & 0.6279 \\
\hline
\end{tabular}

The results above of model heteroskedasticity tests are explained in Table 8. No heteroskedasticity in the residual, therefore null hypothesis not rejected because the probability value of the R-square is more than 5 per cent (probability more than 0.05 significant level observed). This means that the probability value is $26.43 \%$ which is a significant level is higher than $5 \%$. Based on this result it is not heteroscedastic, but homoscedastic in terms of residues of model 3.

Table 9: Serial Correlation Test for Model 3

\begin{tabular}{|l|l|l|l|}
\hline Breusch-Godfrey Serial Correlation LM Test \\
\hline F-statistic & 0.005511 & Prob. F(1,2) & 0.9476 \\
\hline Obs*R-squared & 0.013740 & Prob. Chi-Square(1) & 0.9067 \\
\hline
\end{tabular}

Whether its serial correlation that is autocorrelation or serial correlation in the residual should not be both of it. Table 9 shows that the R-squared observed is more than 5 per cent ( 90.67 per cent) of the corresponding probability. Hence it is impossible to reject the null hypothesis and it there is no serial correlation in the residual, rather it is accepted. Consequently, in model 3 there is no autocorrelation or serial correlation.

\section{Model 4}

Table 10: OLS Model 4 result for (LURT $=B_{0}+$ LGDPT)

\begin{tabular}{|l|l|l|l|l|}
\hline Variable & Coefficient & Standard Error & T-Statistic & Probability \\
\hline C & -9.781976 & 11.34098 & -0.862534 & 0.4518 \\
\hline LGPDT & 1.705236 & 0.919994 & 1.853531 & 0.1609 \\
\hline R-squared & 0.533841 & Adjusted R-squared & \\
& & & Prob (F-Statistic) & 0.160860 \\
\hline F-statistic & 3.435575 & & 0.3785 \\
\hline
\end{tabular}

Note: Significant level: $5 \%$

Table 10 above presents the ordinary least square method model for LURT = LGPDT for the sample of 5 years' time series data observation in Selangor Malaysia. In this result, the equation formed as:

$$
\mathrm{HCl}=-9.781976+1.705236+\varepsilon
$$

Whereby, LURT is represented unemployment rate and LGDPT for gross domestic product and $\varepsilon$ represents the error term. LURT and LGDPT have a negative relationship. If LGDPT increase by $1 \%$ LURT will be decreased by 1.705236 units. The unemployment rate (LURT) and gross domestic product collection in the country of Malaysia, therefore, it not inverse relations. It means that the unemployment rate not changed if gross domestic product collection is significant whether it increase 
or decrease. It is not a significant relationship because the probability value is higher than 5 per cent. This test does not reject the null hypothesis as the $p$-value is higher than the value of 5 per cent. In this estimated model, the value of R2 is $0.5338(53.0 \%)$ which means that the good fitness of the predicted regression line is $53.0 \%$. It is thus understood that the model 4 estimated regression line is nicely fitted.

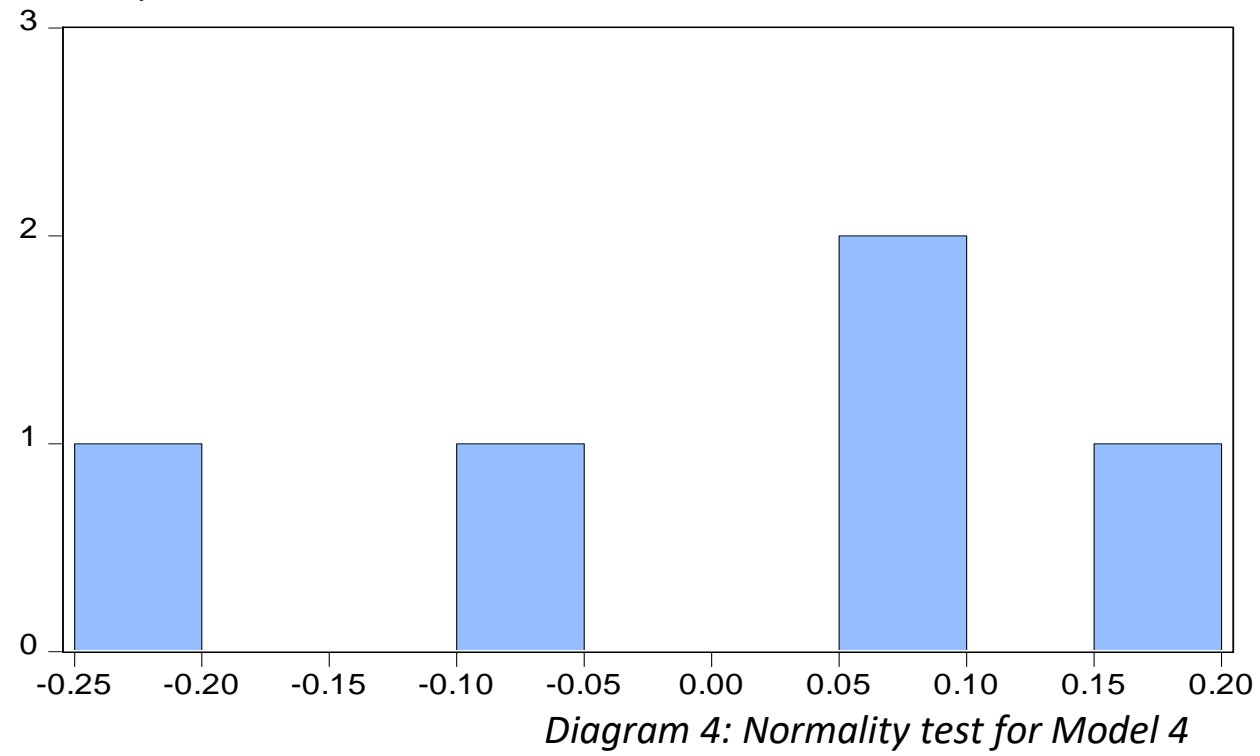

Series: Residuals

Sample 20122016

Observations 5

Mean

Median

Maximum

Minimum

Std. Dev.

Skewness

Kurtosis

Jarque-Bera

Probability
$-2.13 e-15$

0.060040

0.160670

$-0.206879$

0.144128

$-0.440124$

1.862873

0.430811

0.806214

The normality test for model 4 is presented in Diagram 4 . The residual should normally be distributed based on a good model. The "residual is normally distributed" is null hypothesis is accepted as the corresponding Jarqure-Bera probability value is more than $5 \%(80.6 \%)$ also this is the equivalent value. This is means do not reject the null hypothesis. Therefore, "The residual is not normally distributed" is rejected in the alternative hypothesis. It shows the model 4 is a good model.

Table 11: Heteroskedasticity Test for Model 4

\begin{tabular}{|l|l|l|l|}
\hline Heteroskedasticity Test: Breusch-Pagan-Godfrey \\
\hline F-statistic & 0.701000 & Prob. F(1,3) & 0.4639 \\
\hline Obs*R-squared & 0.947041 & Prob.Chi-Square (1) & 0.3305 \\
\hline Scaled explained SS & 0.147092 & Prob. Chi-Square(1) & 0.7013 \\
\hline
\end{tabular}

The results of model heteroskedasticity tests are explained in Table 11. No heteroskedasticity in the residual, therefore null hypothesis not rejected because the probability value of the $\mathrm{R}$-square is more than 5 per cent (probability more than 0.05 significant level observed). This means that the probability value is $33.05 \%$ which is a significant level is higher than $5 \%$. Based on this result it is not heteroscedastic, but homoscedastic in terms of residues of model 4.

Table 12: Serial Correlation Test for Model 4

\begin{tabular}{|l|l|l|l|}
\hline \multicolumn{4}{|l|}{ Breusch-Godfrey Serial Correlation LM Test } \\
\hline F-statistic & 0.016426 & Prob. F(1,2) & 0.9097 \\
\hline Obs*R-squared & 0.040731 & Prob. Chi-Square(1) & 0.8401 \\
\hline
\end{tabular}


Whether its serial correlation that is autocorrelation or serial correlation in the residual should not be both of it. Table 12 shows that the R-squared observed is more than 5 per cent ( 84.01 per cent) of the corresponding probability. Hence it is impossible to reject the null hypothesis and it there is no serial correlation in the residual, rather it is accepted. Consequently, in model 4 there is no autocorrelation or serial correlation.

\section{Results of Correlation}

Table 13: Correlation Analysis (Significant level 5\%)

\begin{tabular}{|l|l|l|l|l|}
\hline Variables & HCl & LGDPT & LURT & LZKT \\
\hline HCI & 1.000000 & - & - & - \\
\hline LGDPT & -0.998541 & 1.000000 & - & - \\
\hline LURT & -0.765527 & 0.730644 & 1.000000 & - \\
\hline LZKT & -0.988911 & 0.993549 & 0.677353 & 1.000000 \\
\hline
\end{tabular}

By using the correlation analysis this aspect helps to clarify the relationship as well as the performance and direction among each variable of research. From the table 13 above shown gross domestic product, unemployment rate and zakat are observed to be negatively correlated with poverty $(\mathrm{HCl})$, but the relationship differs for unemployment rate because of it statistically insignificant however both gross domestic product and zakat have significant with level $5 \%$. This indicates that a higher collection of zakat and gross domestic product induces alleviating poverty.

After that, for gross domestic product, a positive but statistically insignificant correlation is found to the unemployment rate. Despite that, the collection of zakat is indicated as positive with the probability of 0.0006 lower than the significance level, it means statistically significant. With regards, there is a statistically significant positive relationship of unemployment rate with zakat at a significant level of $5 \%$. to the unemployment rate. 
INTERNATIONAL JOURNAL OF ACADEMIC RESEARCH IN BUSINESS AND SOCIAL SCIENCES

Vol. 9, No. 6, June, 2019, E-ISSN: 2222-6990 @ 2019 HRMARS

\section{Results of Granger Causality}

Table 14: Granger Causality Test (Significant level 5\%)

\begin{tabular}{|c|c|c|}
\hline \multicolumn{3}{|l|}{ Pairwise Granger Causality Tests } \\
\hline Null Hypothesis: & F-Statistic & Prob. \\
\hline LURT does not Granger Cause $\mathrm{HCl}$ & -0.99945 & 1.0000 \\
\hline $\mathrm{HCl}$ does not Granger Cause LURT & 1.17765 & 0.4740 \\
\hline LGDPT does not Granger Cause $\mathrm{HCl}$ & -1.00000 & 1.0000 \\
\hline $\mathrm{HCl}$ does not Granger Cause LGDPT & 0.10006 & 0.8050 \\
\hline LZKT does not Granger Cause $\mathrm{HCl}$ & -0.99999 & 1.0000 \\
\hline $\mathrm{HCl}$ does not Granger Cause LZKT & 0.06607 & 0.8398 \\
\hline LGDPT does not Granger Cause LURT & 1.22885 & 0.4673 \\
\hline LURT does not Granger Cause LGDPT & 0.00036 & 0.9880 \\
\hline LZKT does not Granger Cause LURT & 0.75892 & 0.5438 \\
\hline LURT does not Granger Cause LZKT & 5.29423 & 0.2610 \\
\hline LZKT does not Granger Cause LGDPT & 7.17822 & 0.2274 \\
\hline LGDPT does not Granger Cause LZKT & 0.00011 & 0.9934 \\
\hline
\end{tabular}

The causational relationship between Zakat collections, Employment Rates, the Head Count Index $(\mathrm{HCl})$ and the Gross Domestic Product is described in Table 14 above. Refers from that the null hypothesis "LURT does not Granger cause $\mathrm{HCl}$ " can be accepted, because the probability is larger than $5 \%$ level of significance $(1.0000>0.05)$. Hence, the total unemployment rate cannot cause the poverty head count index. Following, null hypothesis " $\mathrm{HCl}$ does not Granger Cause LURT" cannot be rejected, must accept because the probability is larger than $5 \%$ significance level $(0.4740<0.05)$. Also, the head count index cannot Granger cause the total unemployment rate. Therefore, both variable $\mathrm{HCl}$ and LURT had an independence causality relationship.

Furthermore, this "Log (Zak) does not cause of $\mathrm{HCl}$ " in the table above instead, it means the null hypothesis is not rejected because the $p$-value is larger than the significant level at 5 per cent and it is 1 per cent higher than 0.05 per cent. Consequently, Zakat collection cannot significantly lead to the Head Count Index(poverty). No rejection of the null hypothesis of " $\mathrm{HCl}$ does not cause of log (Zakat)," The Head Count Index, therefore, cannot cause Zakat collection to a considerable extent. Therefore, the relationship between the Zakat collection and poverty status $(\mathrm{HCl})$ is one way causational. In the meantime, the whole Log (Gross Domestic Product), Head Count Index ( $\mathrm{HCl}), \log$ (Unemployment Rate) and Log (Zakat) are all related to the independence causational relationship because all $p$-values of variables are larger than $5 \%$ level significant.

Lastly, the null hypothesis is not rejected based on "LZKT does not Granger Cause LGDPT" because the $p$-value is larger than the significant level at 5 per cent. Therefore, the zakat collection cannot cause the gross domestic product. Following from that, "LGDPT does not Granger Cause LZKT" null hypothesis is not rejected depending on a level significantly and both of this variable is independence causality relationship. 
INTERNATIONAL JOURNAL OF ACADEMIC RESEARCH IN BUSINESS AND SOCIAL SCIENCES

Vol. 9, No. 6, June, 2019, E-ISSN: 2222-6990 @ 2019 HRMARS

\section{Results of Hodrick-Prescott Filter}

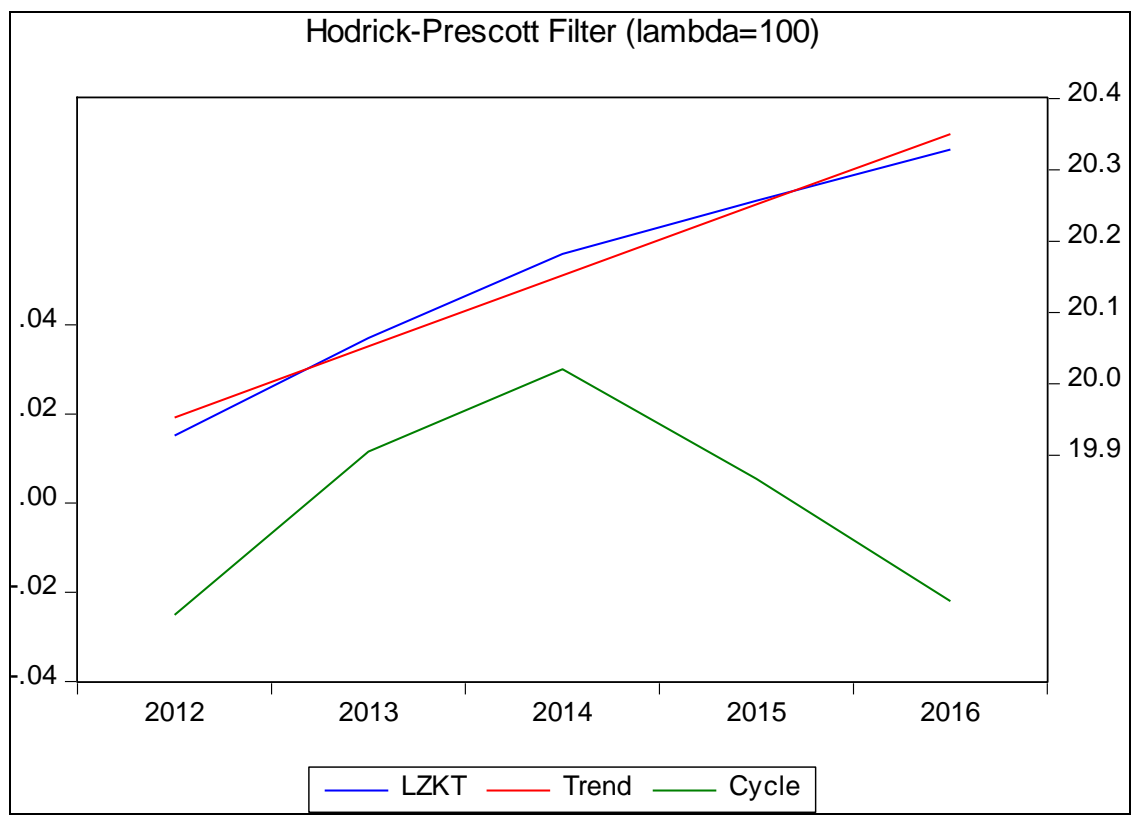

Figure 1: Trend and Fluctuations - LZKT

The trends and fluctuations of the Zakat collection over the time period are shown in Figure 1. One of the most commonly used tools in macroeconomics is the Hodrick-Prescott (HP) filters. It is also used to remove a trend component from time series data of different Lambda smoothing values. The phase of Zakat collection in the time sequence is much less fluctuating, given the similar pattern in Zakat's collection for the time series process. Zakat collecting process is the same. And the pattern is stochastic, not deterministic, of this time sequence. Therefore, in this time series, there are fewer structural breaks. The tendency of the Zakat collection is slowing down in the long run.

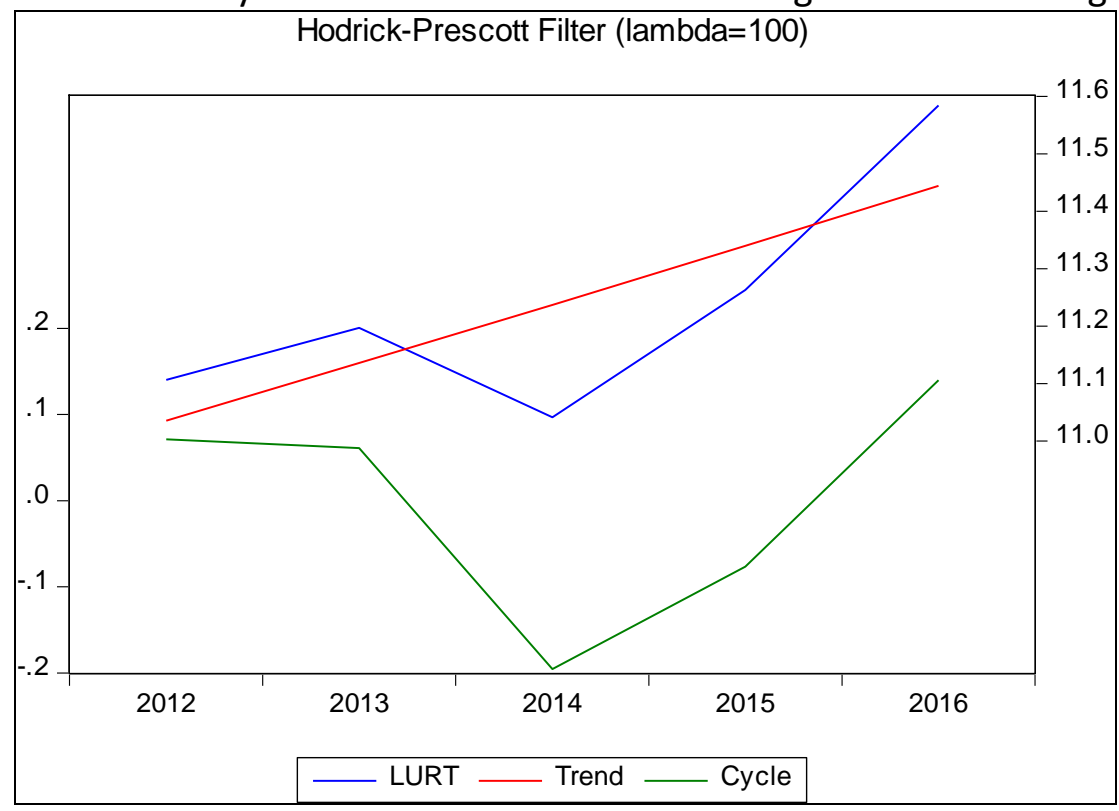

Figure 2: Trend and Fluctuations - LURT 
Figure 2 above shows the Unemployment Rate is used in Hodrick-Prescott to come by trend and economic cycles. That an upward graph from 2012 LURT, Trend and Cycle a large increase follows until the end of 2016 examined period and both indicated value is estimated at $11.55 \% 11.43 \%$ and 11.1\%. However, in 2014 both LURT and Cycle falling sharply. The cycle or fluctuation well into the total Unemployment Rate through the researched data series is very less as since the cycle of the LURT time series similarly supports the LURT trend. And this time series pattern is also stochastic, not deterministic. Therefore, in this time series, there are fewer structural breaks. The tendency of the Zakat collection is slowing down in the long run.

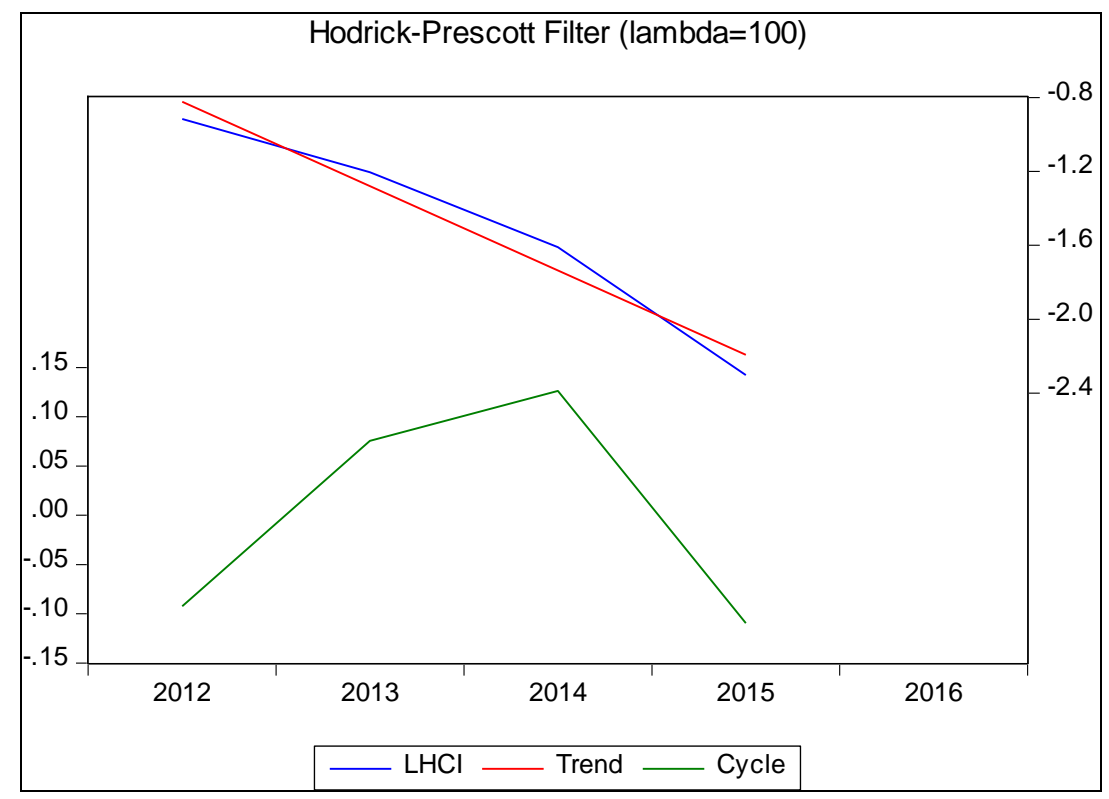

Figure 3: Trend and Fluctuations $-\mathrm{HCl}$

Figure 3 shows the $\mathrm{HCl}$ (poverty status) trend and fluctuations over the period. The Head Count Index $(\mathrm{HCl})$ fluctuation or cycle over the data series deemed seems to be lower, as a time series cycle of the $\mathrm{HCl}$ possesses to the significant $\mathrm{HCl}$ trend. The trend is also significantly stochastic, not considerably deterministic for this time series. Thus, in this time series, there are significantly fewer structural breaks. Over the long term, the form of the $\mathrm{HCl}$ trend is declining. 
INTERNATIONAL JOURNAL OF ACADEMIC RESEARCH IN BUSINESS AND SOCIAL SCIENCES Vol. 9, No. 6, June, 2019, E-ISSN: 2222-6990 @ 2019 HRMARS

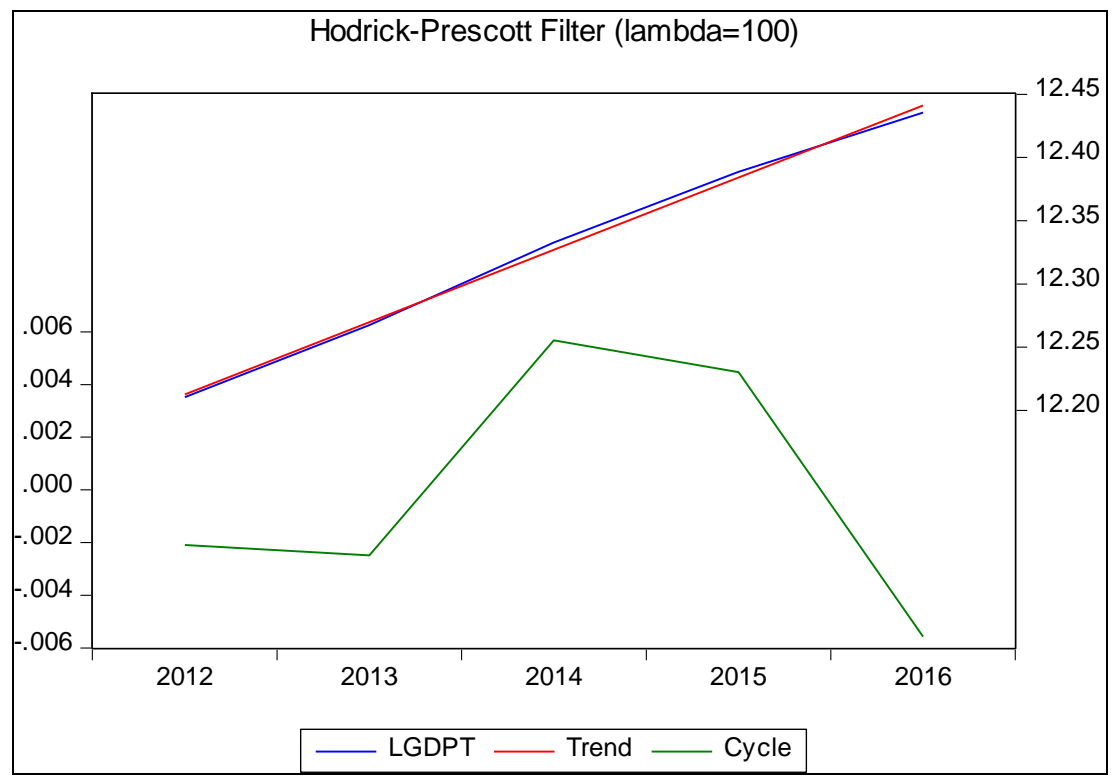

Figure 4: Trend and Fluctuations - LGDPT

Figure 4 above shows the Gross Domestic Product is used to estimate economic cycles. That an upward graph from 2012 LGDPT and Trend a large increase follows until the end of 2016 examined period and both indicated value is estimated at $12.44 \%$. The cycle or fluctuation well into the total Gross Domestic Product through the researched data series is very less as since the cycle of the LGDPT time series similarly supports the LGDPT trend. And this time series pattern is also stochastic, not deterministic. Therefore, in this time series, there are fewer structural breaks. The tendency of the Zakat collection is slowing down in the long run.

\section{Summary of Final Results}

The results show that hypotheses 1 and 2 are supported but hypotheses 3 and 4 are not supported based on the results that using E-views 10. 
INTERNATIONAL JOURNAL OF ACADEMIC RESEARCH IN BUSINESS AND SOCIAL SCIENCES Vol. 9, No. 6, June, 2019, E-ISSN: 2222-6990 @ 2019 HRMARS

\begin{tabular}{lll}
\hline HYPOTHESES & RESULTS & $\begin{array}{l}\text { SUPPORTED/NOT } \\
\text { SUPPORTED }\end{array}$ \\
\hline $\begin{array}{l}\mathbf{H}_{\mathbf{1}}: \text { There is a significant relationship } \\
\text { between } \mathrm{HCl} \text { with } \mathrm{ZKT}\end{array}$ & Supported \\
\end{tabular}

$\mathrm{H}_{2}:$ There is a significant relationship between It is significant
$\mathrm{HCl}$ with GDP

$\mathbf{H}_{3}$ : There is a significant relationship between It is not significant Not Supported UR with ZKT

$\mathrm{H}_{4}$ : There is a significant relationship between It is not significant Not Supported UR with GDP

The times series regression model in this study has passed the normality test with resulting all model have normally distributed which is the probability of Jarque-Bera above on $50 \%$ and do not reject the null hypothesis. Furthermore, there is no autocorrelation in the residual and heteroskedasticity problem existed in the model. Following by, Granger causality shown have independence causational relationship for those all model and for Hodrick-Prescott time series pattern also stochastic, not deterministic. The results from E-views 10 showed that zakat and gross domestic product give an impact to poverty and unemployment rate measured by data collected, as discussed in previous paragraphs, either positive or negative. The results in this section have been valid and have been incoherent with previous research. Next of this chapter, would explain the conclusion, limitations or recommendations of the study.

\section{Conclusions and Recommendations}

This study was conducted with the objective to examine the relationship between zakat and gross domestic product to the unemployment rate and poverty in Selangor using the data set covering the years 2012 to 2016 whether the result shows either impact decreasing or increasing to the dependent variable. Furthermore, this study used 6 tests to run tests such as Ordinary Least Squares (OLS), Normality test (JB), Heteroskedasticity test (BP), Serial Correlation (BG), Correlation test, GrangerCausality, and Hodrick-Prescott (HP).

There are significant relations between poverty and collection in the results. The poverty and the zakat collection have an inverse relationship. Thus, if the amount zakat collected has increased to one per cent, the decrease of head count index in Selangor to alleviation poverty is 0.987, compared to the increase of gross domestic product which has an important relationship between the two variables, with 6.892 units of decreased nature of poverty $(\mathrm{HCl})$. Meanwhile, the correlation analysis is a statistically significant relationship between gross domestic product and zakat perfect negative relationship exists. This indicates that a higher collection of zakat and gross domestic product induces alleviating poverty. This specific objective achieves in this study is been accomplished 
by based on the result that has been conducted 'to examine the impacts between collection zakat to poverty and unemployment rate'.

Furthermore, the second dependent variable is the unemployment rate there is a negative significant relationship between unemployment rate and the collection of zakat, if there is a $1 \%$ increase in the collection of zakat, there is 0.8997 unit of increase of unemployment rate in Selangor whereas there are 6.893 units of decrease in the unemployment rate due to the decrease in GDP without significant relationship between both the variables. In the meantime, the correlation analysis is not a statistically significant relationship between gross domestic product and zakat to the unemployment rate and perfect positive relationship exists. This shown dependent variable does not give effect to decrease the unemployment rate in Selangor. This specific objective achieves in this study is been accomplished by based on the result that has been conducted 'to investigate the impacts between of gross domestic product to poverty and unemployment rate'.

Based to the causality test, there is a one-way causal relationship between head count index, zakat, unemployment rate, and gross domestic product whereas there is not any causal relationship between all variables which is null hypothesis is accepted at $5 \%$ significant level. The normality of all model test is normally distributed and homoscedastic and there is no autocorrelation in the residual of the model. It can be stated that the zakat distribution perspective is much larger statistically than the gross domestic product in the Selangor.

Policymakers and the Malaysian Government in Selangor State can be notified that the results of this study have been used to adopt the appropriate macro-economic strategic management of their fiscal policies for reducing poverty within Muslim communities. First, the future researches are encouraged to the general public to be aware of the importance of zakat can reduce the poverty in Selangor and this has supported by previous researchers stated that all the zakat accumulations have made impressive contributions effect to their domestic economies, social life, and healthy condition. However, there only minimal impact from gross domestic product to minimize to poverty otherwise it undertakes benefits to the unemployment rate. In addition, the unemployment rate also has an impact on the gross internal product, both at state and country that government to take exertion.

\section{Acknowledgements}

The authors would like to thank for the financial support from Universiti Malaysia Sarawak (UNIMAS) and Research Grant Scheme F01/SpSTG/1575/2017. All remaining flaws are the responsibilities of the author.

\section{References}

Abdul Latif, M. D. (1998). Zakat management and administration in Malaysia. Kertas kerja dibentangkan di Seminar of zakat and Taxation di Universiti Islam Antarabangsa Malaysia.

Abdul Majid, M. Z. (2003). Pengurusan Zakat. Kuala Lumpur: Dewan Bahasa dan Pustaka.

Ahmad, S. \& Wahid, H. (2005). Persepsi agihan zakat dan kesannya terhadap pembayaran zakat melalui institusi formal. Jurnal Ekonomi Malaysia, 39(January 2005), 53-69. Retrieved from http://journalarticle.ukm.my/7796/\%5Cnhttp://www.ukm.my/penerbit/jurnal_pdf/JEM3903.pdf

Ali, M., \& Fahme, A. (2011). Role of Zakat in Poverty Reduction in Kelantan, Malaysia (Masters thesis). 
INTERNATIONAL JOURNAL OF ACADEMIC RESEARCH IN BUSINESS AND SOCIAL SCIENCES

Vol. 9, No. 6, June, 2019, E-ISSN: 2222-6990 @ 2019 HRMARS

Universiti Putra Malaysia.

Osman, A. A. (2007). Potensi pembayar dan kutipan zakat di Malaysia. Kertas kerja dibentangkan dalam Konvensyen Zakat dan Cukai Peringkat Kebangsaan di PV/TC, Kuala Lumpur, 22-24 Mei 2007.

Fahme, A., Ali, M., Noor, Z. M., Ridhwan, M., Aziz, A., \& Ibrahim, M. F. (2013). Impact of Zakat Distribution on Poor and Needy Recipients : An Analysis in Impact of Zakat Distribution on Poor and Needy Recipients: An Analysis in Kelantan, (December).

Fazeela, M. F. (2014), "The Role of Zakat in Generating Income Equality in Ampara District", Thesis, Department of Social Sciences, SEUSL.

Hadroj, A. (n.d.). Unemployment - theoretical overview, 564-571.

Hussain. (2010). A Coherent Relationship between Economic Growth and Unemployment: An Empirical Evidence from Pakistan. Human and Social Sciences, Vol. 5, No(3), Hussain, dkk. 2010. A Coherent Relationship betwee. https://doi.org/10.1136/bmjopen-2012-001791Rosly, S. A. (2008). Malaysia and Islamic Economics, International Center for Education in Islamic Finance (INCEIF), (Paper presented at the Hadhari Economics Roundtable Conference, Universiti Kebangsaan Malaysia, 25th November 2008, MALAYSIA)

Ibrahim, P. (2006). Economic role of zakat in reducing income inequality and poverty in Selangor. Unpublished PhD Thesis. Universiti Putra Malaysia.

Ibrahim, P. (2007). Peranan Agihan Zakat Dalam Meningkatkan Tahap Ekonomi Ummah. Kertas Kerja dalam konvesyen Zakat dan Cukai peringkat Kebangsaan, PWTC, Kuala Lumpur. 22-24 Mei.

Jaelani, A. (2015). Zakah Management for Poverty Alleviation in Indonesia and Brunei Darussalam, MPRA Paper No. 69646, posted 22 February 2016 14:56 UTC, Available at: https://mpra.ub.uni/muenchen.de/69646/1/MPRA_paper_69646

Jaradat, M. A. (2013). Impact of inflation and unemployment on Jordanian GDP. Interdisciplinary Journal of Contemporary Research In Business, 4, 317-334.

Johari, F. (2004). Keberkesanan zakat dalam mengatasi masalah kemiskinan di negeri Melaka. Unpublished Master Dissertation. Kuala Lumpur: Akademi pengajian Islam, University Malaya.

Kabir Hassan, M., \& Masrur Khan, J. (2007). Zakat, External Debt and Poverty Reduction Strategy in Bangladesh. Journal of Economic Cooperation, 28(4), 1-38.

Kadri, Z., Ahmad, S., \& Mohd Noor, M. A. (2012). Zakat as A Catalyst to Economics Development: Towards High-Income Country. Persidangan Kebangsaan Ekonomi Malaysia Ke VII (PERKEM VII) Transformasi Ekonomi Dan Sosial Ke Arah Negara Maju, 2, 1263-1273.

Khan, A. Q., Khattak, N.-R., \& Hussain, A. (2008). INTER-DEPENDENCIES AND CAUSALITY IN THE MACROECONOMIC VARIABLES : EVIDENCE FROM PAKISTAN ( 1960-2005 ), 24(1).

Kwasi, A. (2017). Growth, inequality, and poverty reduction in developing countries: Recent global evidence. Research in Economics, 71(2), 306-336. https://doi.org/10.1016/j.rie.2016.05.005

Onwachukwu, C. I. (2015). Does unemployment significantly impact on economic growth in Nigeria? Global Journal of Human-social Science: E Economics, 15(8), 22-26.

Ramli, R., \& Ibrahim, P. (2010). Kesan Agihan Zakat dalam Membasmi Kemiskinan dan Ketidakseimbanngan Agihan Pendapatan di Negeri Sembilan. Persidangan Kebangsaan Ekonomi Malaysia ke-V (PERKEM). 15-17 October 2010, organized by Pusat Pengajian Ekonomi Fakulti Ekonomi \& Pengurusan, Universiti Kebangsaan Malaysia (UKM). 
Ravallion, M. (n.d.). Looking beyond Averages. World, (February 2001).

Suheera, M. Y. M., Nashri, M. M. J., \& Jamaldeen, A. (2015). The Role of Zakat on Poverty Alleviation : An Empirical Study At Nintavur, Sri Lanka. Fia, (1), 157-163.

Wahid, H., \& Ahmad, S. (2009). Pengagihan Zakat oleh Institusi Zakat kepada Lapan asnaf. Ekonomi Dan Kewangan Islam, 1-17.

Wahid, H. (2011). Localization of Zakat Distribution and The Role of Mosque: Perceptions of Amil and Zakat Recipents in Malaysia. International Zakat Forum 2011, 1-25. https://doi.org/10.1007/s13398-014-0173-7.2

Wahid, H., \& Abdul Kader, R. (2011). Cadangan Melokalisasikan Pengagihan Zakat di Malaysia: Peranan Institusi Masjid. Perkem Vi, 1, 124-137. 